\title{
Development of Entrepreneurship among Rural Women
}

\author{
Kiranjot Sidhu and Sukhjeet Kaur \\ Department of Extension Education, Punjab Agricultural University, \\ Ludhiana 141001, Punjab, India
}

KEYWORDS Employment; rural youth; social system; resources

\begin{abstract}
Entrepreneurship is the only solution to the growing employment among rural youth. It helps to generate employment for number of people within their own social system. This is more beneficial for women in rural areas as it enable them to add to the family income while taking care of their farm, home and livestock centered tasks. Rural women possess abundant resources to take up an enterprise. She has the benefit of easy availability of farm and livestock based raw material and other resources. Hence she can effectively undertake both production and processing oriented enterprises. But to be a successful entrepreneur, women should process certain fundamental qualities beside the support of the family and government organizations. Entrepreneurial development among rural women helps to enhance their person capabilities but also decision making status in the family and society as a whole.
\end{abstract}

\section{INTRODUCTION}

Development of the society is directly related with the income generation capacity of its members. With agriculture as the key income generation activity the entrepreneurship based on farm and home can directly affect the income of a major chunk of our population. The growth of modernization processes such as industrialization, technical change; urbanization and migration further encourage it. Entrepreneurship on small scale is the only solution to the problems of unemployment and proper utilization of both human and non human resources and improving the living conditions of the poor masses.

Kuratko and Richard (2001) in their book on entrepreneurship stated that it is the dynamic process of creating incremental wealth. This wealth is created by individuals who take the major risks in terms of equity, time and career commitment of providing value to some product or services the product or service itself may or may not be new or unique but value must somehow be infused by the entrepreneur by securing and allocating the necessary skill and resources. In other words it is the application of energy for initiating and building an enterprise.

Rural women's participation in agro based activities is much more than what statistics reveal. This is mainly due to the fact that most of the work done by the women at farm and home is disguised as daily chores. Mechanization and

Address correspondence to: Kiranjot Sidhu Telephone: 0161-504097(R), 09814098405(M)

E-mail: sidhs64@hotmail.com easy availability of labour provide more time to energetic women to engage themselves in self employment or entrepreneurial ventures. Rural women having a pool of human and non human resources to take up an enterprise need only an innovative mind and motivation. But a successful entrepreneur requires some essential pre requisites.

Objective: To develop entrepreneurial empowerment strategies based upon the participation of rural women in farm and home system.

\section{METHODOLOGY}

In order to capture the contribution of women in varied area of her work the data was generated through case studies representing the five agroclimatic zones of Punjab. The participatory approach was used to study each case. Ten cases each of five distinct landholding categories namely landless, marginal, small, medium and large from each zone were studied. The qualitative data was thus generated from 250 rural families represented by the female decision maker of the family.

\section{FINDINGS}

Rural women play a vital role in farm and home system. She contributes substantially in the physical aspect of farming, livestock management, post harvest and allied activities. Her direct and indirect contribution at the farm and home level along with livestock management operations has 
not only helped to save but has also led to increase in family income.. She performs various farm, livestock, post harvest and allied activities and possesses skills and indigenous knowledge in these areas. This is in spite of her being the socially suppressed, educationally at a disadvantageous position and having a little say in the decision making process due to lack of independent income source in hand. Present era of mechanization, easy and cheap availability of labour in Punjab has led to availability of free time. Hence it becomes imperative to empower them technically so as to cope with the changing times and productively use her free time and existing skills for setting and sustaining enterprises. This will not only generate income for the family but also improve the decision making capabilities of the rural women leading to overall empowerment.

\section{Areas for Micro-enterprise Development}

Variations in role performance and direct and indirect contribution varied within the state depending on number of factors ranging from landholdings, subsidiary occupations, agroclimatic conditions, and socio-personal characteristics of the rural women and her family members. Based upon the results of the case studies the following areas for micro-enterprises development are suggested:

Micro-enterprise Development Related to Agriculture and Allied Agricultural Activities: Women have been performing agricultural operations and have been very actively participating in seed selection, seed treatment and vegetable growing. They can be trained and motivated to adopt micro-enterprises in which her skill and patience can be exploited. Ali (1997) in his paper on post harvest processing of agricultural produce stated that value addition includes processes like sorting, grading, cutting, seeding, shelling and quality packaging etc.. Growing of organic vegetables, flowers, oilseeds and seed production are some of the areas beside taking up mushroom growing and bee-keeping . Some more areas can be like dehydration of fruits and vegetables, canning or bottling of pickles, chutneys, jams, squashes, dairy and other products which are ready to eat.

Micro-Enterprise Development Related to Livestock Management Activities: The major share of work is being handled by women in performance of livestock management operations. Hence this area needs to be exploited for microenterprise development. Empowerment of women through formation of self help groups and all women dairy and poultry cooperatives can help women to control the decision making and the financial aspects of livestock management. Livestock feed production and production of vermi-compost using the animal waste can be an important area in which women can utilize both her technical skills and raw material from the farm and livestock to earn substantial income. Value addition to livestock based raw material and establishment of small scale agro-processing units can benefit the women.

Micro-enterprise Development Related to Household Based Operations: Women perform many household tasks besides looking after the needs of the family. This involves taking care of the children, cooking cleaning the house etc. but at the same time she is equipped with skills such as knitting, stitching, weaving, embroidery etc. Bakery and flour milling are some more examples of the enterprises that can be taken up by women in this area of her activity.

\section{Personal and Environmental Prerequisites for Entrepreneurial Development}

\section{Extension Strategies to Promote Entrepreneurship}

Creating Awareness: Awakening of rural women to the possibilities of the easily accessible micro-enterprises is the foremost task. The government, semi- government and nongovernment organizations should create awareness among the most productive age group of rural women. The printed media can be effectively put to use for the purpose.

Motivating Entrepreneurs: Psychological stimulation is the prerequisite for putting any idea virtually into action. For proper motivation of rural women, the economic, social and health benefits of various possible enterprises should be highlighted. The use of farm visits, video film shows, dramas, puppet shows, group meeting etc. will help in motivating the potential group.

Expertise Development: After awakening and motivating the next step in development and success of an enterprise is the acquisition of knowledge and skill up-gradation and polishing of existing knowledge and skills in production, 
Table 1 Personal and environmental prerequisites for entrepreneurial development

\begin{tabular}{ll}
\hline Personal prerequisites & Environmental prerequisites \\
\hline Powerful urge & Availability of infrastructural facilities \\
Strong determination & Venture capital availability \\
Hard work & Technically skilled labour \\
Risk bearing capacity & Accessibility of suppliers. \\
Emotional maturity & Proximity of supporting organization/institution \\
Knowledge: & Attitude of the area population \\
- Technical & \\
- Legal & \\
- Marketing & \\
Administrative skills & \\
Far sightedness. & \\
Innovativeness & \\
Ability to use available resources & \\
Previous experience/entrepreneurial parents & \\
Education &
\end{tabular}

processing, packaging and marketing techniques are the basic requirements. . Saha (1999) also emphasized the need of value addition as it ensures high premium to the producer. He stated that India ranks second in food production but only two percent of the produce is processed .In addition to this, knowledge regarding accessibility to loans, various funding agencies, procedures regarding certification etc. should be provided.

Lectures, printed material, discussions, institutional and non institutional skill trainings for imparting first hand technical knowledge in production, processing, procurement and management should be provided to rural women who are interested or already engaged in various enterprises.

Education in direct and indirect marketing of the produce and finance management should be in-built component of future training programmes for women.

Continuous Follow-up: Constant follow- up should be ensured for the sustainability of a $\mathrm{e}$ micro-enterprises. During this phase various constraints such as personal, social, economic, marketing etc. faced by entrepreneurs should be addressed. Possible help in the form of knowledge, technical skills and inputs should be provided to enable them to solve their problems.

\section{Benefits of Entrepreneurship to Rural Women}

Empowering women particularly rural women is a challenge. Micro- enterprises in rural area can help to meet this challenge. Micro-enterprises not only enhance national productivity, generate employment but also help to develop economic independence, personal and social capabilities among rural women. Following are some of the personal and social capabilities which are developed as a result of taking up enterprise among rural women:

- Economic empowerment

- Improved standard of living

- $\quad$ Self confidence

- Enhanced awareness

- Improvement in decision making status

- $\quad$ Sense of achievement

- Increased social interaction

- Improvement in leadership quality

\section{CONCLUSION}

Rural women perform variety of operations in farm and home system and have basic indigenous knowledge, skill, potential and resources which can prove helpful to establish and manage enterprises. What they need is awareness, motivation, technical skill and support from family, govern-ment and other organization. With the right assistance they can strengthen their capacities besides adding to the family income and national productivity.

\section{REFERENCES}

Ali, N. 1997. Post harvest processing of agriculture produce for high quality and export. Theme paper published in Souvenir of XXXI Annual convention of Society of Agricultural Engineers, Agricultural Engineering, PAU, Ludhiana.

Kuratko, Donald, F.and Richard, M Hodgetts. 2001. Entrepreneurship - A Contemporary Approach . New York, U.S.A: Harecourt College Publishers

Saha, S. 1999. "Value addition - A USP for Processed Food." Agriculture Today, 2(5): 46-47 